Polónyi István

egyetemi tanár, Debreceni Egyetem Bölcsésztudományi Kar

\title{
A hazai felsőoktatás-politika átalakulásai
}

A tanulmány célja a magyar felsóoktatás-politika rendszerváltást követó átalakulásainak bemutatása részint a felsóoktatási törvények

és azok módosításainak vizsgálatával, részint a minisztériumi vezetés személyi jellemzối néhány vonatkozásának ismertetésével. A felsóoktatási törvények változásai nyomán egyre inkább szúkül az

egyetemi autonómia (amit az OECD 2003-as Education Policy Analysis autonómia-indikátorainak segitségével értékelünk), és egyre jelentốsebb a központi irányitás, amit a törvények tartalmának és terjedelmének változásaival lehet érzékelni.

Ugyanakkor ellentmondásos a hazai felsóoktatási szakpolitika formálóinak professzionalizációja, amelynek következtében új

kormányokkal új szakpolitikusok jönnek, akik a szakpolitikát minduntalan újra- és újraformálják.

A változások nyomán alaposan átformálódik a magyar felsóoktatás: egy klasszikus humboldti típusú, magas autonómiájú rendszerból, amely elé a széles tömegek befogadásának és az értelmiségképzésnek

a célját állitották, egy nagyon erôsen központból irányitott, szúk autonómiájú, munkaerópiaci célokat szolgáló szakképzó rendszerré kezd átalakulni.

Ebben az írásban a hazai felsőoktatás-politika rendszerváltást követő formálódását igyekszünk bemutatni részint a felsőoktatási törvények és azok módosításainak vizsgálatával, részint a minisztériumi vezetés személyi jellemzőinek néhány vonatkozását ismertetve.

\section{A felsőoktatási törvények}

A hazai felsőoktatási törvények áttekintése két aspektusból jellemzi jól a felsőoktatás-politikát. Részint a törvénymódosítások száma az oktatáspolitika stabilitásáról nyújt képet, részint a módosítások tartalmának az autonómiára gyakorolt hatása a felsőoktatás-politika centralizációját jellemzi.

Az intézményi autonómiát az OECD (2003) szerint az alábbi indikátorok alapján jellemezhetjük:

1. saját tulajdonúak-e az épületek és a felszerelések;

2. tetszés szerint vehetnek-e fel kölcsönöket az intézmények;

3. szabadon alakíthatják-e költségvetésüket saját céljaik elérése érdekében;

4. maguk alakítják-e ki struktúrájukat és az oktatás tartalmát;

5. maguk döntenek-e az oktatói kar tagjainak felvételéről és elbocsátásáról;

6. önállóan állapíthatják-e meg a fizetéseket a meglévő jogszabályi kereteken belül;

7. maguk határozzák-e meg a hallgatói létszámot;

8. saját hatáskörben döntenek-e a tandíjakról. 
Fontos hozzátenni, hogy 1990 és 2011 között az alkotmányban más egyetemi autonómia-szabályozás volt érvényben, mint azt követően.

Az alkotmány 1989-es módosítása nyomán a szövegbe bekerül, hogy „a Magyar Köztársaság tiszteletben tartja és támogatja a tudományos és múvészeti élet szabadságát, a tanszabadságot és a tanítás szabadságát". ${ }^{1}$ A 2011-ben elfogadott Alaptörvény viszont így ír: „,... a felsőoktatási intézmények a kutatás és a tanítás tartalmát, módszereit illetően önállóak, szervezeti rendjüket törvény szabályozza. Az állami felsőoktatási intézmények gazdálkodási rendjét törvény keretei között a Kormány határozza meg, gazdálkodásukat a Kormány felügyeli." '2 Az új megközelítés nyilvánvalóan leszükíti az egyetemi autonómiát, kiemelve abból a szervezetalakítást és a gazdálkodást. (A fenti indikátorok közül az első négyet.)

A következőkben áttekintjük a felsőoktatási törvényeket és azok legfontosabb módosításait, s utalunk a változtatás autonómiára gyakorolt hatására.

\section{3. évi LXXX. törvény}

Az államszocializmus utolsó oktatási törvénye, az 1985. évi I. törvény elég sokáig hatályos maradt, mert a felsőoktatás készülő törvényének egyeztetése igencsak hosszúra nyúlt. Ezt a jogszabályt az 1990. évi XXIII. törvény tette szalonképessé, de még nem választotta szét a közoktatás és a felsőoktatás szabályozását.

A felsőoktatás első törvényének előkészítése meglehetősen elhúzódott. Részint azért, mert az Antall-kormány miniszterei nagyon nehezen egyeztek meg abban, hogy az addig különböző tárcák által irányított felsőoktatási intézmények egységesen az oktatási tárca alá kerüljenek. Részint pedig azért, mert az Akadémia nehezen mondott le tudományos minősítési jogáról. A kormány első oktatási minisztere, Andrásfalvy Bertalan nem is volt képes véglegesíteni a törvényt, így végül is a második miniszter, Mádl Ferenc tudta azt Országgyülés elé vinni. Így 1993-ban fogadta el a Parlament az első felsőoktatási törvényt (1993. évi LXXX.), amely egészen 2005-ig hatályos maradt. Négy kormányciklust kiszolgált, és mindössze 37-szer módosították, ami a későbbi törvények sorsát látva igen jelentős stabilitást jelent. Persze igen jelentős módosításokon is átesett. A legjelentősebb talán a tandíj 1995. évi bevezetése, majd 1998. évi eltörlése, illetve a költségtérítéses (és az államilag támogatott) képzés 1996-os bevezetése (azaz a hallgatók egy része számára a tanulás fizetőssé tétele). A magyar felsőoktatás-politika ellentmondásosságára jól jellemző, hogy miközben a tandíj körül nagypolitikai összecsapások zajlottak, létéről népszavazás döntött, $\mathrm{s}$ annak eredménye nyomán a kormány eltörölni kényszerült, addig a költségtérítés (ami lényegében pontosan ugyanúgy tandíj) eltérő pártösszetételü kormányokon keresztül a mai napig érintetlenül fennmaradt. Pedig sokkal igazságtalanabb, mint az eltörölt tandíj, mert miközben a tandíjfizetés hatásait több különböző, szociális helyzettől és tanulmányi teljesítménytől függő kedvezményezés igyekezett részben kompenzálni, addig a költségtérítéses hallgatók semmilyen támogatást nem kapnak (és 2006-ig még hitelt sem vehettek fel), miközben nyilvánvalóan több közöttük a hátrányos helyzetü.

A '93-as törvény, amely (105 ezer karakteres terjedelmével) a rendszerváltás utáni felsőoktatás szabályozás legkarcsúbb, valóban keretjellegü törvénye volt, lényegében egy humboldti típusú felsőoktatási szerkezetet és intézményirányítást teremtett meg, amelyet a szenátus (akkor még intézményi tanács) és a rektor osztott hatásköre jellemzett. Továbbá az elöl bemutatott autonómia-elemek közül az első háromban és az utolsóban némi megkötésekkel, a többiben viszont lényegében majdnem teljes autonómiát adott az intézményeknek. 
A Horn-kormány (és Fodor Gábor rövid, majd Magyar Bálint első minisztersége) alatt a törvényt 11-szer módosították, s ezek a módosítások jelentős oktatáspolitikai irányváltásokat jelentettek. Az 1996-os törvénymódosítás változtatott a szenátus és a rektor osztott hatáskörén, ekkortól a rektor gazdasági téren egyszemélyi felelős vezető (amivel a szenátus hatalma csökkent). Ugyanekkor helyezik a gazdasági főigazgató kinevezését miniszteri hatáskörbe. Ezzel párhuzamosan az államháztartás szabályozásáról szóló törvény '96-ra azt is egyértelművé teszi, hogy a korábbi (köztestületi, közintézeti, közalapítványi) elképzelésekkel szemben a felsőoktatási intézmények költségvetési szervek, amelyeknek a gazdálkodása igen kötött (ld. erről részletesebben: Polónyi, 2002, 2006). Ezek voltak az első lépések a hazai felsőoktatás autonómiájának szükítésére. A Horn-kormány alatt a törvény terjedelme megduplázódott (200 ezres karakterszámúra), de még mindig kerettörvény jellegü volt.

Az első Orbán-kormány (Pokorni Zoltán és Pálinkás József minisztersége) alatt a törvényt 13-szor módosították. A 98-as kormányváltást követően a már említett tandíjeltörlés után, 1999-ben igen radikális módosítást fogad el az Országgyülés, a hálózatracionalizálást, amelynek során az intézményi integrációk nyomán az állami felsőoktatási intézmények száma 55-ről 30-ra csökkent (az egyetemek száma 25-ről 17-re, a főiskolák száma 30-ról 13-ra). Majd 2000-ben egy újabb módosítás az egyetemi tanári kinevezéseket a Magyar Akkreditációs Bizottság (MAB) jóváhagyásához köti. Az autonómia tehát tovább szükül. A törvény terjedelme ebben a kormányciklusban nem sokat, mintegy 5 százaléknyit bővül.

A 2002-es kormányváltást követően hatalomra került Medgyessy-kormány régi-új minisztere (Magyar Bálint) azonnal nekifog egy új felsőoktatási törvény elökészítésének, azonban az - a '93-as törvényhez hasonlóan - ismét elhúzódott, s majd csak 2005 végén fogadja el a Parlament, így lényegében az egész ciklus alatt a régi, '93-as törvény maradt hatályban. Ezen két fontos módosítást hajtanak végre. Az egyik az intézményi felvételi vizsgák eltörlése, s felvételinek „hozott” eredményekhez kötése, és ezzel központosítása. Majd 2005-ben, az új felsőoktatási törvény késlekedése miatt a kétszintü képzést is a '93-as törvény módosításával vezetik be. Ennek végrehajtása, tehát a képzési programok kidolgozása, lényegében központosítva történik. Mindkettő jelentősen csökkenti az autonómiát, hiszen ettől kezdve a hallgatók kiválasztása nem az intézmény hatásköre, és a tananyag-alakításban is nagyon leszükül az intézményi mozgástér. A Medgyessy/ Gyurcsány-kormányok alatt 10-szer módosították a '93-as felsőoktatási törvényt (ez alatt a kormányciklus alatt a törvény 10 százaléknyit bővül, s hatályon kívül helyezésekor mintegy 250 ezer karakter terjedelmü volt). A ciklus végén fogadják el a felsőoktatásról szóló 2005. évi CXXXIX törvényt (amelynek az életbelépése 2006-ra húzódik át, miután az államelnök beadványára az Alkotmánybíróság alkotmányellenesnek ítéli annak egyes részeit).

\section{5. évi CXXXIX törvény}

Az új felsőoktatási törvény hatályba lépése alig előzi meg az új kormány hatalomra lépését. Az új felsőoktatási törvény egyébként messze nem keretjellegü, terjedelme (389 ezer karakter) több mint háromszor akkora, mint a '93-a törvényé.

A törvény legfontosabb újdonsága a kétszintü képzési szerkezet bevezetése (lényegében a 93-as törvény 2005-ös ezzel kapcsolatos módosító szövegének szószerinti átvétele) mellett az új vezetési szisztéma, amely az AB oppozíciója után nem annyira radikális, mint amennyire az eredeti elképzelések voltak. A szenátus és a rektor mellett megjelenik a Gazdasági Tanács, amely külső tagokat is bevonva a gazdálkodási, vagyongazdálkodási kérdésekben tanácsadó szerv. Fontos változás a szervezet önálló alakításának nagyobb szabadsága, a karok szerepének háttérbe szorítása is. A törvény finanszírozási garanci- 
ákat is tartalmaz, amely a gazdálkodás kiszámíthatóságát javítja azzal, hogy a képzési normatívákat a nemzetgazdasági bruttó átlagkeresethez köti. A törvény jelentős gazdálkodási szabadságot biztosított.

A törvény tehát, miközben növelte az autonómiát az elöl látott tényezők közül az első háromban (a gazdálkodási területen), valamint az intézményi struktúra alakítása területén, azonközben megtartotta a kötöttségeket a képzési tartalom alakításában, a felvételi rendszerben és az egyetemi tanárok MAB általi véleményezésében.

A második Gyurcsány-, majd Bajnai-kormányok (és Hiller István minisztersége) alatt 25-ször (tehát évente nagyjából 6-szor) módosítják a felsőoktatási törvényt. A módosítások elég jelentős oktatáspolitikai váltást hoztak a korábbi elképzelésekhez viszonyítva. Először a felsőoktatási intézményekre vonatkozó adókedvezményeket törölték el. Majd az intézmény önálló társaságalapítási jogosultságát korlátozták. 2007-ben törlik a képzési normatíva nemzetgazdasági átlagkeresethez való kötését, ami jelentősen rontja a finanszírozás kiszámíthatóságát. Ezt részben ellensúlyozza, hogy bevezetik a három éves fenntartói megállapodást. A törvény a módosítások nyomán egyre részletesebben szabályozza az intézményi gazdálkodással, tulajdonlással kapcsolatos, de a kormányzati feladatokat is. Ennek nyomán terjedelme közel harmadával növekedett (487 ezer karakterre). A kormányciklus alatt a gazdasági tanács hatáskörét - jóllehet tanácsadó szervről van szó - számtalanszor módosították. A kormányciklus utolsó évében hozott törvénymódosítás lehetővé tette volna a felsőoktatási intézmények átsorolását az államháztartási törvényben akkor létrehozott „,vállalkozó közintézet” kategóriába, amely jelentősebb gazdasági önállóságot biztosított volna, s egyben az intézményvezetést is átalakította volna, a gazdálkodás felügyeletét ellátó „,vezető testületet” létrehozva. (Azért csak „volna”, mert az államháztartási és vele a felsőoktatási törvénynek ezt a módosítását a kormányváltást követően az új kormány ugyanez év őszén eltörölte.)

\section{1. évi CCIV. törvény}

A második Orbán-kormány egyik első ténykedése az Alaptörvény, majd új oktatási törvények Parlament elé vitele.

A 2011. évi CCIV., a nemzeti felsőoktatásról szóló törvény jelentős újdonságokat hozott. Az eddig államilag finanszírozott hallgatókat ösztöndíjas hallgatónak nevezi át, $\mathrm{s}$ az állami ösztöndíjas hallgató (kötelező hallgatói szerződés alapján) végzés után meghatározott időt idehaza kell ledolgozzon. Témánk szempontjából fontos újdonság a rektor kiválasztásának, a szenátus helyett, miniszteri (fenntartói) hatáskörbe adása. Hasonlóan miniszteri hatáskör a gazdasági föigazgató és a belső ellenőr kinevezése is, amelyekben a minisztert nem köti a rektor javaslata. A felvételi keretszámok elosztásában is visszajön a miniszter allokációs joga. Ezek igen jelentős autonómia-szűkítést jelentenek. Mint ahogy a Magyar Felsőoktatási Akkreditációs Bizottság összetételének átalakítása is (ezt az eddigi törvények alapján alapvetően az akadémiai delegáltak - azaz a Rektori Konferencia delegáltjai - dominálták), amelyet az új felsőoktatási törvény úgy változtatott meg, hogy abban a kormányzat képviselöi legyenek többségben. A felsőoktatás másik, eddig intézményi delegáltakból álló testülete, az FTT is radikálisan átalakul: miniszteri tanácsadó testület lesz, miniszter által kiválasztott képviselökböl. Tehát a felsőoktatási intézmények kollektív érdekképviseletében meghatározó szerepet játszó három testület: az Akkreditációs Bizottság, az FTT és a rektorok miniszteri kiválasztása után a Rektori Konferencia is kormányzati kontroll alá kerül. Ezzel lényegében minden autonómia-elem, amit elöl felsoroltunk, erősen korlátozottá válik.

A törvényt már a második Orbán-kormány alatt, a hatályba lépését követö két évben 17-szer módosítják (bár ennek kb. felét a fokozatos életbeléptetés teszi ki). A módosí- 
tások nyomán az eredeti 267 ezer karakteres terjedelmü törvény majdnem harmadával növekszik, 349 ezer karakterre, majd 2014 végéig, a harmadik Orbán-kormány első féléve alatt 370 ezerre. Az egyik jelentős módosítás a felvételi vizsga lehetőségének részbeni visszaadása az intézményeknek. A másik a gazdasági tanács szerepének eliminálása: a törvény eredeti változatában kötelező létrehozás 2013-ban lehetőséggé válik, majd 2014-ben megszünik. A 2014-es módosítással a felsőoktatási intézményvezetésben új elemként megjelenik a kancellár, aki az ,állami felsőoktatási intézményben az intézmény müködtetését" végzi. A kancellárt a miniszterelnök nevezi ki, s lényegében minden gazdálkodási és szervezeti kérdésben döntési jogköre van. A rektor (akinek választása visszakerül az egyetemhez) - és a szenátus - lényegében csak oktatási ügyekben rendelkezik döntési jogosítvánnyal. Az autonómia-indikátorokon áttekintve látszik, hogy a vagyoni, gazdálkodási (beleértve a tandíj - vagyis önköltség - megállapítását is), és az intézményi struktúrát meghatározó tényezőket a kormányzat a kancelláron keresztül irányítja, a szakirányonkénti és intézményi felvehető létszámokat a minisztérium tételesen kontrollálja. Jóllehet a felvételi részbeni visszakerülése és a rektorválasztás visszaadása a szenátus hatáskörébe valamennyit javít a helyzeten, mégis a felsőoktatási intézmény autonómiája igen szükre lett szabva.

\section{A felsőoktatási törvények módosításainak tanulságai}

Jól követhető a törvénymódosítások számának és a törvények terjedelmének alakulása az 1. táblázaton.

1. táblázat. A törvénymódositások alakulása

\begin{tabular}{|c|c|c|c|c|c|c|}
\hline & Kormány & Törvény & \multicolumn{2}{|c|}{$\begin{array}{l}\text { Módositások } \\
\text { száma }\end{array}$} & $\begin{array}{l}\text { Évi átlagos } \\
\text { módositás }\end{array}$ & $\begin{array}{c}\text { A törvény terjedelmének } \\
\text { változása }\end{array}$ \\
\hline 1990-1994 & Antall & \multirow[t]{4}{*}{ 1993. évi } & 3 & \multirow{4}{*}{37} & 3,00 & $111 \rightarrow 105$ \\
\hline 1994-1998 & Horn & & 11 & & 2,75 & $105 \rightarrow 200$ \\
\hline 1998-2002 & Orbán 1 & & 13 & & 3,25 & $200 \rightarrow 212$ \\
\hline \multirow{2}{*}{$2002-2006$} & \multirow{2}{*}{$\begin{array}{l}\text { Medgyessy/ } \\
\text { Gyurcsány } 1\end{array}$} & & 10 & & \multirow{2}{*}{2,50} & $212 \rightarrow 257$ \\
\hline & & \multirow[t]{3}{*}{ 2005. évi } & - & \multirow{3}{*}{42} & & 389 \\
\hline 2006-2010 & $\begin{array}{l}\text { Gyurcsány 2/ } \\
\text { Bajnai }\end{array}$ & & 25 & & 6,25 & $389 \rightarrow 487$ \\
\hline \multirow{2}{*}{ 2010-2014 } & \multirow{2}{*}{ Orbán 2} & & 17 & & \multirow{2}{*}{$\begin{array}{c}8,50 \\
(6,75)^{3}\end{array}$} & $487 \rightarrow 450$ \\
\hline & & \multirow[t]{2}{*}{ 2011.évi } & 17 & \multirow{2}{*}{20} & & $267 \rightarrow 349$ \\
\hline $2014-$ & Orbán 3 & & 3 & & (6) & $349 \rightarrow 370$ \\
\hline
\end{tabular}

Az adatok jól mutatják az egyes kormányok szabályozási kedvét. Szembetűnő, hogy 2006 után milyen lendületet vett a törvénymódosítási hajlandóság. A törvénymódosítások áttekintése alapján elég egyértelmü, hogy azok kormányciklusról kormányciklusra igen jelentős oktatáspolitikai irányváltásokat takarnak. Egyértelmü, hogy a hazai felsőoktatás-politikában nincs hosszú távú, összefüggő koncepció. A különböző kormányok koncepciói egymással inkább versengenek, mintsem egymásra épülnének.

Kissé árnyalja a képet, ha végignézzük a felsőoktatási törvényekben és azok jelentősebb módosításaiban a felsőoktatás céljait, illetve annak átalakulását. 
Az államszocializmus utolsó oktatási törvénye, az 1985. évi I. törvény indokolása (a 94-96. §-hoz) a „szocialista értelmiségi szakemberképzést” emeli ki mint a felsőoktatás feladatát. Az ideológiai nevelés mellett a gazdaság igényei szerinti szakemberképzés az alapfeladat.

A Németh-kormány alatt az 1990. évi XXIII. törvény a felsőoktatási intézményalapítás plurálissá tétele mellett a felsőoktatásba történő bejutás könnyítéséről ír, előrevetítve a felvételi vizsgarendszer megszüntetését.

Az Antall-kormány által beterjesztett 1993. évi felsőoktatási (1993. évi LXXX.) törvény általános indoklásában a minőség megőrzése és a képzési rendszernek a nyugat-európai normákhoz való igazítása mellett a felsőoktatási képzésben részesülők korosztályi arányának növelését, a nyugat- és észak-európai átlaghoz viszonyított elmaradásunk csökkentését hangsúlyozza.

A Horn-kormány által előterjesztett 1996. évi LXI. törvény a '93-as felsőoktatási törvényt több helyen is radikálisan módosítja, s a Preambulumát is kiegészíti azzal, hogy ,a felsőoktatás mint kiemelt jelentőségü ágazat iránt az Országgyülés különös felelösséget érez, ennek szellemében mindent megtesz annak érdekében, hogy a megfelelö korosztályból a felsőoktatásba bekerülő hallgatók létszáma a fejlett demokratikus társadalmakban elért szintre emelkedhessék".

Az első Orbán-kormány idején született 1999. évi LII. (a felsőoktatási intézményhálózat átalakításáról, továbbá a felsőoktatásról szóló 1993. évi LXXX. törvény módosításáról szóló) törvény az intézményhálózat átalakításának indokait a következőkben jelöli meg:

- ,az ország felemelkedése, a magyar társadalom átalakulása,

- a regionális kapcsolatok erősítése,

- a szellemi erőforrások egyesítése,

- a nemzetközileg is elismert, versenyképes munkaerő képzése,

- a felsőoktatási kutatás és oktatás fejlesztése és

- a müvelődéshez való jog kiterjesztése érdekében".

Eszerint tehát a felsőoktatásnak a versenyképes munkaerő képzése a fő célja.

Az első Gyurcsány-kormány alatt született 2005. évi CXXXIX. törvény a felsőoktatásról bevezetőjében arról ír, hogy a felsőoktatásnak képesnek kell lenni a korszerű ismeretek létrehozására, közvetítésére és átadására a társadalmi kohézió, a fenntartható fejlődés, a nemzetközi versenyképesség, a technológiai innováció kívánatos mértékének fenntartása érdekében. Tehát lényegében a felsőoktatás externáliáit azonosítja mint célokat.

A második Gyurcsány-kormány által beterjesztett 2007. évi CIV. törvény (a felsőoktatásról szóló 2005. évi CXXXIX. törvény módosításáról) indoklásában a következőket írja: „A felsőoktatás a munkaerő-piaci igényekkel összhangban meghatározott szakszerkezetű képzési kínálatot nyújtó, európai színvonalon versenyképes, minőségi képzést folytató, az országos és nemzetközi kutatás fejlesztésben, innovációban sikeresen részt vevő, hatékonyan gazdálkodó, gazdasági és akadémiai kérdésekben szakértelemmel irányított, a kapcsolataiban nyitott felsőoktatás hálózat-átalakítását és müködtetését tüzte célul."

A második Orbán-kormány által előterjesztett 2011. évi CCIV., a nemzeti felsőoktatásról szóló törvény bevezetője azzal indokolja az új törvény megalkotását, „hogy gyermekeink és unokáink tehetségükkel, kitartásukkal, s lelkierejükkel ismét felemelik Magyarországot". A törvény általános indoklása a felsőoktatás elmúlt évtizedekbeli torzulásait, „munkaeröpiaci követelmények szempontjából alig hasznosítható végzettséget nyújtó" alapszakokat emlegetve, hangsúlyozza, hogy az új jogi keretek megteremtése „,nemzetstratégiai célokat követve egy olyan felsőoktatási rendszer jogi kereteit szabályozza, mely a versenyképes tudás átadásával, a közjót szolgálva, a nemzet szellemi és 
gazdasági fejlődésének biztosítéka". A részletes indokolás az első szakaszhoz a következő magyarázatot füzi: ,,a felsőoktatási törvény szabályozási célja, a versenyképes tudás átadásához, megszerzéséhez szükséges felsőoktatási intézményrendszer megteremtése, az egész nemzet felemelkedésének, stabil erkölcsi, szellemi, gazdasági alapokon nyugvó jövőnk érdekében az Alaptörvényben foglaltak szerint egy erős egyetemi polgárság kialakítása."

A fenti áttekintésből jól látható, hogy az államszocialista időszak ideológiai és munkaerőpiaci megközelítése után a '90-es évek végéig a felsőoktatás elé elsődleges célként a fejlett országok felsőoktatási mintáit s az expanziót állították. A 2000-es évek elején az első Orbán-kormány a felsőoktatás új céljaként a versenyképes munkaerő képzését emeli ki. Az öket váltó baloldali kormányok is a nemzetközi versenyképességet, majd a munkaeröpiaci igények kielégítését hangsúlyozzák. A második és harmadik Orbán-kormány ismét erősen ideológiai megközelítést fogalmaz meg: a gazdasági haladást és a nemzet szellemi fejlődését, valamint a munkaerőpiaci igények szolgálatát. Ez utóbbi az indoklásban ugyan nem jelenik meg, de az államilag támogatott helyek elosztásának a törvényben és végrehajtási rendeletekben követett elvei alapján egyértelmü.

Végeredményben tehát a hazai felsőoktatás feladat-meghatározásában a különbözö kormányok össze nem egyeztetett koncepciói ellenére elég egyértelmű átalakulási ív látszik: a '90-es évek társadalmi indíttatású felsőoktatás-célkitüzését elöször a gazdasági versenyképességet szolgáló, majd a munkaerőpiaci igények kielégítését megjelölő célkitüzése váltja fel (2. táblázat).

2. táblázat. A felsőoktatással kapcsolatos törvényekben a felsőoktatás feladatazonositásai

\begin{tabular}{|c|c|}
\hline Törvény & $\begin{array}{c}\text { A preambulumban, illetve bevezetöben vagy az általános indoklásban } \\
\text { a felsöoktatás céljai, feladatai }\end{array}$ \\
\hline $\begin{array}{l}\text { 1985. évi } \\
\text { I. törvény }\end{array}$ & $\begin{array}{l}\text { Szocialista értelmiségi szakemberképzés, a gazdaság igényei szerinti } \\
\text { szakemberképzés. }\end{array}$ \\
\hline $\begin{array}{l}\text { 1990. évi } \\
\text { XXIII. törvény }\end{array}$ & A felsőoktatásba történő bejutás könnyítése. \\
\hline $\begin{array}{l}\text { 1993. évi } \\
\text { LXXX. törvény }\end{array}$ & $\begin{array}{l}\text { A képzési rendszernek a nyugat-európai normákhoz való igazítása, a felsőoktatási } \\
\text { képzésben részesülők korosztályi arányának növelése, a nyugat- és észak-európai } \\
\text { átlaghoz viszonyított elmaradásunk csökkentése. }\end{array}$ \\
\hline $\begin{array}{l}\text { 1996. évi } \\
\text { LXI. törvény }\end{array}$ & $\begin{array}{l}\text { A megfelelő korosztályból a felsőoktatásba bekerülő hallgatók létszáma a fejlett } \\
\text { demokratikus társadalmakban elért szintre emelkedhessék. }\end{array}$ \\
\hline $\begin{array}{l}\text { 1999. évi } \\
\text { LII. törvény }\end{array}$ & $\begin{array}{l}\text { Az ország felemelkedése, a regionális kapcsolatok erősítése, a szellemi erőforrások } \\
\text { egyesítése, a nemzetközileg is elismert, versenyképes munkaerő képzése, a } \\
\text { felsőoktatási kutatás és oktatás fejlesztése. }\end{array}$ \\
\hline $\begin{array}{l}\text { 2005. évi } \\
\text { CXXXIX. törvény }\end{array}$ & $\begin{array}{l}\text { Korszerü ismeretek létrehozása, közvetítése és átadása, a társadalmi kohézió, a } \\
\text { fenntartható fejlődés, a nemzetközi versenyképesség, a technológiai innováció. }\end{array}$ \\
\hline $\begin{array}{l}\text { 2007. évi } \\
\text { CIV. törvény }\end{array}$ & $\begin{array}{l}\text { A munkaerőpiaci igényekkel összhangban meghatározott szakszerkezetü képzési } \\
\text { kínálatot nyújtó, európai színvonalon versenyképes, minőségi képzést folytató } \\
\text { felsőoktatás. }\end{array}$ \\
\hline $\begin{array}{l}\text { 2011. évi } \\
\text { CCIV }\end{array}$ & $\begin{array}{l}\text { „Gyermekeink és unokáink tehetségükkel, kitartásukkal, s lelkierejükkel ismét } \\
\text { felemelik Magyarországot. mely a versenyképes tudás átadásával, a közjót } \\
\text { szolgálva, a nemzet szellemi és gazdasági fejlődésének biztosítéka. Versenyképes } \\
\text { tudás átadásához, megszerzéséhez szükséges felsőoktatási intézményrendszer } \\
\text { megteremtése, az egész nemzet felemelkedésének, stabil erkölcsi, szellemi, gazdasági } \\
\text { alapokon nyugvó jövőnk érdekében az Alaptörvényben foglaltak szerint egy erős } \\
\text { egyetemi polgárság kialakítása.” }\end{array}$ \\
\hline
\end{tabular}


Ezzel együtt egyre erőteljesebb lesz az állami irányítás és egyre szükebb körű a felsőoktatási intézményi autonómia. Az elöl ismertetett OECD autonómia-indikátorok alapján a hazai intézményi önállóság átalakulását a 3. táblázat szemlélteti.

3. táblázat. A hazai felsőoktatás autonómiájának változása

\begin{tabular}{|c|c|c|c|c|c|c|}
\hline & 1994 & 1998 & 2002 & 2006 & 2010 & 2014 \\
\hline tulajdonlás & részben & részben & NEM & RÉSZBEN & NEM & NEM \\
\hline $\begin{array}{l}\text { kölcsön-fel- } \\
\text { vétel }\end{array}$ & NEM & IGEN & NEM & IGEN & NEM & NEM \\
\hline $\begin{array}{l}\text { költségve- } \\
\text { tés szabad } \\
\text { alakítása }\end{array}$ & $\begin{array}{l}\text { RÉSZ- } \\
\text { BEN }\end{array}$ & $\begin{array}{l}\text { NEM, ill. } \\
\text { nagyon kis } \\
\text { részben, }\end{array}$ & $\begin{array}{l}\text { NEM, ill. } \\
\text { nagyon kis } \\
\text { részben, }\end{array}$ & RÉSZBEN & NEM & NEM \\
\hline $\begin{array}{l}\text { struktúra } \\
\text { és oktatási } \\
\text { tartalom } \\
\text { alakítása }\end{array}$ & IGEN & IGEN, & $\begin{array}{l}\text { Struktúra } \\
\text { RÉSZBEN } \\
\text { Oktatási } \\
\text { tartalom } \\
\text { IGEN }\end{array}$ & $\begin{array}{l}\text { Mindkettőt } \\
\text { RÉSZBEN }\end{array}$ & $\begin{array}{l}\text { Mindkettőt } \\
\text { RÉSZBEN }\end{array}$ & $\begin{array}{l}\text { Mindkettőt } \\
\text { RÉSZBEN }\end{array}$ \\
\hline $\begin{array}{l}\text { oktatói kar } \\
\text { tagjainak } \\
\text { felvétele }\end{array}$ & IGEN & $\begin{array}{l}\text { IGEN - DE } \\
\text { gazdasági } \\
\text { föigazgató } \\
\text { kinevezése } \\
\text { miniszteri } \\
\text { hatáskör }\end{array}$ & $\begin{array}{l}\text { IGEN - DE } \\
\text { tanári kineve- } \\
\text { zéshez MAB } \\
\text { jóváhagyás } \\
\text { gazdasági } \\
\text { főigazgató } \\
\text { kinevezés } \\
\text { miniszteri } \\
\text { hatáskör }\end{array}$ & $\begin{array}{l}\text { IGEN - DE } \\
\text { tanári kineve- } \\
\text { zéshez MAB } \\
\text { jóváhagyás } \\
\text { gazdasági fó- } \\
\text { igazgató kineve- } \\
\text { zése miniszteri } \\
\text { hatáskör }\end{array}$ & $\begin{array}{l}\text { IGEN - DE } \\
\text { tanári kineve- } \\
\text { zéshez MAB } \\
\text { jóváha-gyás, } \\
\text { rektor és } \\
\text { főigazgató } \\
\text { kiválasztása } \\
\text { miniszteri } \\
\text { hatáskör }\end{array}$ & $\begin{array}{l}\text { IGEN - DE } \\
\text { tanári kineve- } \\
\text { zéshez MAB } \\
\text { jóváhagyás, } \\
\text { kancellár } \\
\text { kiválasz-tása } \\
\text { és kinevezése } \\
\text { kormányzati } \\
\text { hatáskör }\end{array}$ \\
\hline $\begin{array}{l}\text { fizetés } \\
\text { alakítása } \\
\text { (jogszabályi } \\
\text { kereteken } \\
\text { belül) }\end{array}$ & IGEN & IGEN & IGEN, & IGEN & $\begin{array}{l}\text { IGEN - DE } \\
\text { vezetők } \\
\text { fizetését } \\
\text { korlátozták }\end{array}$ & IGEN \\
\hline $\begin{array}{l}\text { hallgatói } \\
\text { létszám } \\
\text { alakítása }\end{array}$ & IGEN & RÉSZBEN & RÉSZBEN & NEM & NEM & NEM \\
\hline $\begin{array}{l}\text { döntés } \\
\text { tandíjakról }\end{array}$ & IGEN & $\begin{array}{l}\text { RÉSZBEN } \\
\text { (költségtérítést } \\
\text { igen) }\end{array}$ & $\begin{array}{l}\text { RÉSZBEN } \\
\text { (költségtérí- } \\
\text { tést igen) }\end{array}$ & $\begin{array}{l}\text { RÉSZBEN } \\
\text { (költségtérítést } \\
\text { igen) }\end{array}$ & NEM & NEM \\
\hline
\end{tabular}

Ebből a nyolc indikátorból a 4., 5. tekinthető egyértelműen, és a 6., 7. részben az akadémiai autonómia körébe tartozónak. Ha megnézzük a fenti indikátorok alakulását a hazai felsőoktatásban, egyértelműen látszik az autonómia szükülése. Ezen belül az akadémiai autonómia körébe tartozó indikátorok esetében is hasonló tendenciákat tapasztalhatunk.

Hozzá kell tenni, hogy ezek a folyamatok nem egyedülállóak a fejlett világban. A fejlett országok felsőoktatásában a '60-as években elinduló felsőoktatási tömegesedés nyomán nagyszolgáltatókká váló egyetem állami irányítása, autonómiája és intézményi vezetése jelentősen átformálódik a 21 . század elejére.

Az autonómia, amely történelmi kategória, a különböző országokban eltérő módon, de mindenhol változik valamennyit. Mint Fielden (2008) rámutat: az állam által a felsőoktatási intézmények számára biztosított autonómia mértéke legtöbbször örökölt jogok, tradíciók, törvényhozói szándék és társadalmi kultúra keveréke. Általában hosszú idő alatt alakul ki különböző törvényhozási folyamatoknak, miniszteri döntéseknek és szabályozásoknak köszönhetően. Mindezek mellett nagyban meghatározza az egyetemvezetési modellek kialakulását az adott ország kultúrája, így az egyik modell, mely jól működik 
az egyik országban, szinte teljesen elképzelhetetlen lehet a másikban (Fielden, 2008, 18. o.). Négy modellt különböztet meg az autonómia szempontjából: az állami kontrollú, a félautonóm, a fél-független és a független modelleket. Az állami kontrollú modellt a direkt állami irányítás jellemzi, ahol az egyetem olyan, mint egy állami tulajdonú vállalat vagy állami hivatal. A független modellben az egyetem hasonló, mint egy nonprofit szervezet vagy egyesület, ahol a kormányzati kontroll kizárólag a pénzügyekre vonatkozik. A félautonóm és a fél-független az előző két modell között van, amikor a kormányzat közvetve, testületek, illetve hivatalok közbeiktatásával, indirekt módon irányít. Az elsőt kivéve mindegyik modellnél megmarad az akadémiai autonómia valamilyen szintje.

Azt is látni kell, hogy a fejlett országok egyetemeinek felépítésében és irányításában jelentős változások történtek a 20. század második felében. Részint összevontak egyetemeket, részint az intézmények egységei között megerösítették a kapcsolatokat, hogy minél hatékonyabban és gazdaságosabban lehessen müködtetni azokat. A tömegessé vált felsőoktatás egyre fontosabbá vált a politikai szféra számára: a kormányzati szerveknek mind nagyobb aggodalmat jelentett az egyre növekvő, felsőoktatással kapcsolatos kiadás, ezért minden eddiginél jobban érdekeltté vált a kormányzat, hogy befolyásolja a felsőoktatási intézmények termékkínálatát mind a hallgatók, mind pedig a kutatások tekintetében (Bleiklie és Kogan, 2007).

A hazai felsőoktatás-politika tehát a rendszerváltást követő 25 évben mintegy végigrohan azon a fejlődési pályán, amelyen a fejlett országok felsőoktatása több mint fél évszázad alatt járt be. A fejlett országokban egy viszonylag lassú, szerves fejlődést látunk, ahol az egyes változásoknak megvan a kiforrási ideje. A hazai oktatáspolitikai száguldás viszont feszültségekkel, gyakran kiforratlan elképzelések erőltetésével, kapkodással jár.

\section{A felsőoktatási szakpolitika professzionalizálódása}

„A közpolitika [...] olyan szakpolitika, amelyet kormányzati testületek vagy tisztségviselők valósítanak meg" - idézi Andersont (1990) Goodin és Klingemann (2003, 532. o.). Érdemes tehát közelebbről megnéznünk, kik is a legfőbb felsőoktatás-politikai kormányzati szereplök. Ha áttekintünk a rendszerváltást követő oktatásért felelös minisztereken és „eredeti foglalkozásukon”, valamint a felsőoktatásért felelős vezetőkön és „,eredeti foglalkozásukon”, akkor egy igen lassú átalakulást, professzionalizációt állapíthatunk meg.

A rendszerváltást követően napjainkig 11 oktatási tárcavezető volt, közülük „,eredeti foglakozását" tekintve öt jött az akadémiai szférából, 6 pedig politikus. Úgy tünik, növekszik a politikusok aránya ${ }^{4}$, ami azt jelzi, hogy a szakpolitika irányítását a politikusok veszik át.

A miniszteri státusz egyre inkább politikusi státusszá alakulása normális, a politika professzionalizálódását jelző folyamat. A nem politikus miniszter nyilvánvalóan általában gyenge szereplö a kormányon belül.

Ugyanakkor a felsőoktatási tárcaterület irányítását a rendszerváltás óta 2 tisztviselő és 10 vezető egyetemi oktató (egyetemi tanár, illetve egyetemi docens) látta el. Itt viszont a miniszteri poszttal ellentétes folyamatot látunk. E poszt betöltőjének egyre inkább az irányított szférából kell kikerülnie, hiszen részint ő tart kapcsolatot a szférával, részint az autonómia csökkenésével mind több feladat kerül a minisztériumhoz, amelyet olyan személynek kell kontrollálnia, aki érti a szféra müködését. 
4. táblázat. A felsőoktatás irányitás vezetöi, 1989-2015

\begin{tabular}{|c|c|c|c|c|c|c|}
\hline Kormány & -tól & $-i g$ & \multicolumn{2}{|c|}{ Oktatási tárca vezetője } & \multicolumn{2}{|c|}{ Felsőoktatási terület vezetője } \\
\hline Németh & 1989 & 1990 & Glatz Ferenc & akadémikus & Hársfalvy Rezső & tisztviselő \\
\hline \multirow[t]{2}{*}{ Antall } & 1990 & 1993 & $\begin{array}{l}\text { Andrásfalvy Ber- } \\
\text { talan }\end{array}$ & egy. tanár & Bakos István & tisztviselö \\
\hline & 1993 & 1994 & Mádl Ferenc & akadémikus & Kubovics Imre & egy. tanár \\
\hline \multirow{2}{*}{ Horn } & 1994 & 1995 & Fodor Gábor & politikus & Csirik János & egy. tanár \\
\hline & 1996 & 1998 & Magyar Bálint & politikus & Dinya László & egy. tanár \\
\hline \multirow[b]{2}{*}{ Orbán 1} & 1998 & 2001 & Pokorni Zoltán & politikus & Kiss Ádám & egy. tanár \\
\hline & 2001 & 2002 & Pálinkás József & $\begin{array}{l}\text { akadémi- } \\
\text { kus, egy. } \\
\text { tanár }\end{array}$ & Kiss Ádám & egy. tanár \\
\hline $\begin{array}{l}\text { Medgyessy } \\
\text { /Gyurcsány } 1\end{array}$ & 2002 & 2006 & Magyar Bálint & politikus & Mang Béla & egy. docens \\
\hline $\begin{array}{l}\text { Gyurcsány } 2 \\
\text { / Bajnai }\end{array}$ & 2006 & 2010 & Hiller István & politikus & Manherz Károly & egy. tanár \\
\hline Orbán 2 & 2010 & 2014 & $\begin{array}{l}\text { Réthelyi Miklós } \\
\text { Balog Zoltán }\end{array}$ & $\begin{array}{l}\text { egy. tanár } \\
\text { politikus }\end{array}$ & $\begin{array}{l}\text { Dux László } \\
\text { Klinghammer István }\end{array}$ & $\begin{array}{l}\text { egy. tanár } \\
\text { egy. tanár }\end{array}$ \\
\hline Orbán 3 & 2014 & - & Balog Zoltán & politikus & Palkovics László & egy. tanár \\
\hline
\end{tabular}

Viszont az is látszik, hogy a felsőoktatási szférának ez a vezetője nem „éli túl” a kormányzati ciklusokat. Ezen nincs mit csodálkozni, mert mint Pulay (2009) rámutatott: a közigazgatás folyamatosságának és stabilitásának modellje Magyarországon megbukott, „,a magyar gyakorlat nem követte az európai modell szellemiségét”.

A felsőoktatási terület vezetői elvileg szakpolitikai államtitkárok, azaz a felsőoktatási szakpolitika irányítói. Ez azonban a vizsgált időszakban csak akkor volt így, amikor a miniszter átadta ezt a jogosítványt ennek a posztnak, más esetben ez inkább végrehajtó, magyarázó, kommunikáló szerepet jelentett. Például Andrásfalvy minisztersége alatt a terület vezetője valódi formálója volt a szakpolitikának, Mádl minisztersége alatt pedig inkább végrehajtója a miniszter által diktált szakpolitikának. Magyar Bálint alatt inkább végrehajtók voltak, a jelenlegi kormányciklusban inkább formáló szerepe van a terület államtitkárának.

Ellentmondásos tehát a hazai felsőoktatási szakpolitika formálóinak professzionalizációja. Ennek következtében új kormányokkal új szakpolitikusok jönnek, akik a szakpolitikát minduntalan újra és újra formálják.

\section{Befejezésül}

A hazai felsőoktatás rendszerváltás utáni korszakában három felsőoktatási törvény adott jogi keretet a müködésnek. A három törvényt összesen közel százszor módosították. Különösen az utóbbi három kormányciklusban szembetünő az évi 6-7 módosítás, amely esetenként igen jelentős felsőoktatás-politikai váltást takar. (Hozzá kell tenni, hogy az utolsó három évben három jelentősen különböző felsőoktatás-fejlesztési stratégia is született.) Ezek mögött a törekvések mögött az egymást követő kormányok egyre görcsösebb felzárkózni akarása áll.

A hazai kormányok politikai törekvéseiben mindig alapvető törekvés volt a felzárkózás. Ez a '90-es években a felsőoktatás-politikában mint a felsőoktatás felzárkóztatása jelenik meg, majd a 2000-es évek első évtizedében egyre inkább mint a gazdasági felzárkózást kiszolgáló felsőoktatás fogalmazódik meg. Ez a felzárkózni akarás egyre 
kevésbé türi az egyetemi autonómiát, egyre inkább a központosítástól remél eredményeket. Ennek nyomán a felsőoktatás-politika változásai hatására a hazai felsőoktatás egy klasszikus humboldti típusú, magas autonómiájú rendszerből, amely elé a széles tömegek befogadásának és az értelmiségképzés célját állították, egy nagyon erősen központból irányított, szük autonómiájú, munkaerőpiaci célokat szolgáló szakképző rendszerré kezd átalakulni.

Ez csak annyiban hasonlít a fejlett világ felsőoktatás-fejlődésének elmúlt fél évszázadára, hogy a tömegesedéssel mindenhol átalakult a felsőoktatás. Mindenhol növekedett az állami beleszólás, mindenhol elmozdultak az intézmények a gazdálkodói, vállalkozói modell felé (ld. erről: Hrubos, 2004, 2006), és ezzel átalakult a vezetésük. $\mathrm{Az}$ akadémiai vezetés háttérbe szorult, s helyébe egyre inkább a menedzsment lépett, de legalábbis szétvált az akadémiai döntések és a gazdasági döntések rendszere az intézményen belül.

Ezen folyamatok nyomán csökkent az autonómia, de nem szünt meg, mert az egyetemek alapvető értéke, ha úgy tetszik: brandje az akadémiai értékek érvényesülése.

\section{Irodalomjegyzék}

Bleiklie, I. és Kogan, M. (2007): Organization and Governance of Universities. Higher Education Policy, 20. sz. DOI: 10.1057/palgrave.hep. 8300167

OECD (2003): Education Policy Analysis. OECD. DOI: $10.1787 /$ epa-2003-en

Fielden, J. (2008): Global Trends In University Governance. The World Bank, Washington.

Gajduschek György és Hajnal György (2010): Közpolitika. A gyakorlat elmélete és az elmélet gyakorlata. HVG-Orac Kft.

Goodin, E. R. és Kligemann, H. D. (2003): A politikatudomány új kézikönyve. Osiris Könyvkiadó, Budapest.

\section{A hazai kormányok politikai}

törekvéseiben mindig alapvetố törekvés volt a felzárkózás. Ez a

'90-es években a felsóoktatáspolitikában mint a felsốoktatás felzárkóztatása jelenik meg, majd a 2000-es évek elsó évtizedében egyre inkább mint a gazdasági felzárkózást kiszolgáló felsóoktatás fogalmazódik meg. Ez a felzárkózni akarás egyre kevésbé túri az egyetemi autonómiát, egyre inkább a központosítástól remél eredményeket. Ennek nyomán a felsốoktatáspolitika változásai hatására a hazai felsôoktatás egy klasszikus humboldti típusú, magas autonómiájú rendszerból, amely elé a széles tömegek befogadásának és az értelmiségképzés célját állitották, egy nagyon erôsen központból irányitott, szúk autonómiájú, munkaerốpiaci célokat szolgáló szakképzó rendszerré kezd átalakulni.

Hrubos Ildikó (2004): Gazdálkodó egyetem. Új Mandátum Kiadó, Budapest.

Hrubos Ildikó (2006): A 21. század egyeteme. Egy új társadalmi szerződés felé. Educatio, 4. sz.

Polónyi István (2002): A hazai felsőoktatás gazdálkodásának szabályozása. Competitio, 1. sz.

Polónyi István (2006): Vágyak és valóság. A hazai felsőoktatási intézmények gazdasági autonómiájának kérdése az ezredfordulón. In: Kelemen Elemér és Falus Iván (szerk.): Tanulmányok a neveléstudomány köréböl 2005. Müszaki Könyvkiadó, Budapest.

Pulay Gyula (2009): Politikusi és köztisztviselői szerepek a központi közigazgatásban. Új Magyar Közigazgatás, március 


\section{Jegyzetek}

${ }^{1}$ 1949. évi XX. törvény (A Magyar Köztársaság alkotmánya) 70/G. § (1)

${ }^{2}$ Magyarország Alaptörvénye (2011. április 25.) X cikk (3)

${ }^{3} \mathrm{Az}$ új törvény bevezetésének átmenetétől eltekintve.

${ }^{4}$ A második világháború után a rendszerváltásig fele-fele volt az arány: hat akadémikus: Ortutay
Gyula, Erdey-Grúz Tibor, Kónya Albert, Polinszky Károly, Köpeczi Béla, Czibere Tibor és hat politikus: Darvas József, Kállai Gyula, Benke Valéria, Ilku Pál, Nagy Miklós és Pozsgay Imre volt oktatásért felelős tárcavezető. Ezek közül leghosszabb ideig az '56-os pufajkások megszervezője, Ilku Pál, aki 12 évig volt müvelödési miniszter, ami máig a leghosszabb idő ennek a tárcának az élén 45 után. 